\title{
Gender Dimension Of Waves Of Democratization: Abortion And Reproductive Right Between Eastern And Western Europe
}

\author{
Iza Desperak, PhD \\ University of Lodz, Poland
}

doi: 10.19044/esj.2016.v12n1p56 URL:http://dx.doi.org/10.19044/esj.2016.v12n1p56

\begin{abstract}
This paper focuses on the gender dimension of the transition processes of Western and Eastern Europe, which is viewed from the perspective of democratization processes, i. e. waves of democratization. Adding gender perspective to the analysis, results in the reconceptualization of the democratic approach to the transitional processes. As proposed by Charles Tilly, it requires an alternative approach such as de-democratisation. Some examples of countries with a chosen Western and Eastern European transitions system include: Spain, Portugal, Poland, and Romania. During the last fifty years, they showed how politics concerning reproductive rights, especially on the issue of abortion, differentiate between the real shape and the direction of transition processes which leads either to democratization or its complete opposite.
\end{abstract}

Keywords: Democratization, transition, gender, reproductive rights, abortion

\section{Introduction}

Social change is one of key issues in sociology. However, political transitions are the main focus of transitology, and the processes of democratization are central for contemporary discussion on change. Sociologists dealing with the subject of social change do not only include the gender dimension into their analyses, but also point out that gender change of the society is of utmost importance. Manuel Castells in his book titled The Power of Identity (1997) declares the end of the patriarchy. However, Ronald Inglehart and Pippa Norris in The Rising Tide: Gender Equality and Cultural Change Around the World (2003) presented research data; and Anthony Giddenss develops his idea of democratisation processes occurring in the private sphere (The Transformation of Intimacy, 1992). Thus, this is why the study of the gender aspect of democratization processes should be 
developed. Furthermore, recent transition in East and Central European countries offers very interesting material for such analysis.

I.

Democratic transition is one of main processes of social change, as democratization seems to be one of the key systems of political and social changes in the $20^{\text {th }}$ century. Since this system dominated Europe and influenced other continents, democracy seems to be one of the most obvious forms for the political organization of a society.

\section{Waves of Democratization}

The process of democratization is divided into subsequent stages. One of the most popular classifications of the stages of democratization was proposed by Samuel Huntington (1991) as the theory of three waves of democratization. The first one brought democracy to Western Europe and Northern America in the 19th century; the second wave began after World War II; and the third wave began in 1974 of which the Democratization of Latin America and the former Eastern Bloc was part of this wave. Consequently, in the year 1974, the starting point for the third wave was associated with the Carnation Revolution in Portugal. Thus, its later parts can be observed in Eastern Europe; and this is why the objective of this study is to observe what was going on in both Eastern and Western Europe during the last forty years (or more). Furthermore, this study will not deal with the comparison between European and Latin American models of transition, even though it is also an interesting subject in this paper.

\section{Democracy and Gender}

Classical approach to democracy and democratization did not include gender dimension, even though it was discussed by classics such as Plato, Aristotle, and John Stuart Mill. However, during the period of democracy, Charles Tilly describes the process of democratization to be gendered $^{103}$. According to Tilly, democratization involves the process of including certain new groups into the process of decision making by entitling them to vote. At first, only few groups had the right to vote; however, it was extended into some new groups (men mainly), and then, to all male citizens. Finally, this right also considers women of becoming citizens, and other groups of people which were previously excluded from obtaining citizenship e.g. the Blacks in USA.

Today, gender aspect has become a part of the contemporary definitions of democracy. For example, the Freedom House classification of

${ }^{103}$ Ch. Tilly, Democracy, Cambridge University Press, 2007 
political systems (quoted by Tilly) contains among other criteria: personal social freedoms including gender equality, choice of marriage partners, and size of family ${ }^{104}$. Therefore, the latter corresponds to reproductive legal rights and freedoms relating to reproduction and reproductive health. The World Health Organization defines reproductive rights as follows:

Reproductive rights rest on the recognition of the basic right of all couples and individuals to decide freely and responsibly on the number, spacing, and timing of their children, and to have the information and means to do so, and the right to attain the highest standard of sexual and reproductive health ${ }^{105}$.

On the one hand, including reproductive rights into the methodology of classification of political systems reflects the significance of gender equality issue. Thus, political attitude towards reproductive rights is one of the most visible criteria which may be used to classify democratic and nondemocratic systems. State control over reproductive rights is one crucial element that defines the totalitarian system of government. In Europe, both Hitler and Stalin introduced strict laws against abortion. In Asia, specifically in communist China, control over reproductive rights meant the obligatory policy of one child only, and included forced abortions.

Reproductive right have always been at the borderline between the private and the public domain. In the past, they were hidden in private domain; but today, they have entered into the public domain.

\section{Western and Eastern Europe: Herstories divided by the Iron Curtain}

History of reproductive issues differs in various parts of the world today. At the moment, we have observed relative freedom in this aspect in majority of western world. Consequently, we have also experienced some restrictions in some European margins, strong control in some Latin America countries, and a general legal indifference in non-Christian cultures.

Reproductive rights became political only in the $20^{\text {th }}$ century and soon became one of the claims of the feminist movement. The first wave began with the struggle for the access to education and the right to vote. Thus, at the same time, the movement for family planning and contraception was emerging. After achieving the goals set by the first wave, the second part of the feminist movement demanded the right to abortion. However, this right was only restricted to Western countries as Eastern Europe has guaranteed the right to abortion much earlier.

\footnotetext{
104 Checklist Questions and Guidelines, Freedom House website: https://freedomhouse.org/report/freedom-world-2012/checklist-questions-andguidelines\#.VUHSDixYClE [Access April 30th 2015]

${ }^{105}$ http://en.wikipedia.org/wiki/Reproductive_rights\#cite_note-autogenerated1-2
} 
Soviet Union legalized abortion in 1920 under Lenin. In Poland, there were some initiatives to decriminalise abortion in the 30's. Hitler's administration in Germany punished abortion even by death penalty, but provided some exceptions for the Polish inhabitants under the German occupation. Also, Stalin banned abortion in the 30’s.

After the Second World War, Europe was divided into two separate blocks. In the Eastern bloc, abortion became legal around 1956 after Stalin's death in 1953. This was as a result of de-stalinisation regarded as the thaw [Rus. оттепель]. Furthermore, different countries applied various policies to that field; and generally, women gained access to a legal and free abortion. Nevertheless, the Romanian regime of Nicolae Ceausescu banned abortion in 1966. History of anti-abortion policy in Romania has been described by Gail Kligman in her study The Politics of Duplicity: Controlling Reproduction in Ceausescu's Romania (1998). It was also presented in a film by Cristan Mungiu in 2007 titled 4 Months, 3 Weeks, and 2 Days (Romanian: 4 luni, 3 săptămâni şi 2 zile), which later became the winner of the European Film Awards.

Drama on Romanian women could excite western world in the beginning of $21^{\text {st }}$ century. However, in the late sixties, Romanians suffered the same conditions as many women in Western countries. In democratic countries, women and feminist movement could act against changing the law. France and Germany became the leaders of political fight for legalising abortion (achieved in 1975 and 1976, respectively). However, at the same time, Spain and Portugal only faced the end of dictatorships, and they began their democratic transitions and needed more time to obtain the right to abortion. In Spain and Portugal, the first step was making abortion legal only in some exceptional cases (1986 and 1984, respectively). Consequently, abortion on-demand was legalised in Portugal in 2007 and in Spain in 2010, but there are still strong political tensions and the right wing government tried to restrict abortion law passed by their socialist predecessor.

When Western Europe experienced the second wave of feminism, eastern women were not part of it. Firstly, they could not, as Europe was divided by an Iron Curtain. Secondly, when they had few contacts with feminist activists from Western countries, they did not share their ideas.

One of my colleagues, a Polish, who remember those times, recollects her feelings in such a meeting: "While they wanted right to education, to work, and to abortion, we all had all of them guaranteed, and didn’t even appreciate it.”

During those times, Poland became a destination for abortion tourism for Swedish women. Today, abortion in Sweden is legal, while Polish women travel abroad to undergo abortion because it is not legal in Poland anymore. 


\section{Transition in Eastern Europe and Reproductive Issues}

Transition of former Eastern bloc is usually viewed as a democratization process. While democratization in Western Europe meant also opening for gender equality, Eastern and Central Europe transformation was strongly very anti-gender-egalitarian.

However, this phenomenon was first described by Barbara Einhorn in her Cinderella goes to Market (1993). She observed two parallel processes: relegating women to the private sphere in the name of the national interest, ${ }^{106}$ and displacing them from participation in the labour force, thus planting them back squarely in the family, which is their 'primary sphere of responsibility ${ }^{107}$. Both of them did overlap, as they reconceptualise new definition of the role of women. Elizabeth Dunn, who researched one of Polish companies under privatization, observed how the self-identity of a mother determined the working attitudes of female workers engaged in the production of baby food ${ }^{108}$

Those phenomena were observed by Einhorn in four East Central European countries (former GDR, Poland, Hungary, and former Czechoslovakia), but they can be found in all the countries of former East bloc. However, the redefinition of feminity through motherhood is very visible especially in Poland, where abortion was delegalized in 1993. Furthermore, this country ban of abortion is called a 'compromise' and it is believed and declared to be the basement for democracy.

Polish legal code allows abortion in case of some exceptions (danger of mother's health, serious illness of foetus, or pregnancy as a result of a crime). This description reminds us of Spanish previous law, but in practice, it is just opposite. In Spain, those limitations were treated freely. In Poland, the evidence shows that even when the mother's health is endangered, the foetus is unable to live. In other cases, if pregnancy results from crime, legal abortion is not accessible. Consequently, back-alley abortion market in that country flourishes, and this black market is estimated at millions of dollars yearly.

Polish transformation to democracy was accompanied by strict limitation of reproductive rights, resulting in one of the strictest European abortion laws. Therefore, at the same time, Romania selected different pattern for its transition. De-communisation in Romania included rapid reform of abortion laws, resulting in legalising abortion soon after the execution of Ceausescu and his wife.

\footnotetext{
${ }^{106}$ B. Einhorn, Cinderella goes into Market. Citizenship, Gender and Women's Movements in East Central Europe, Verso, London - New York 1993, pp 258-9

${ }^{107}$ ibid., p. 5

${ }^{108}$ E. Dunn, Baby food, Big Business, and the Remaking of Labor, Cornell Univeristy Press, 2004
} 
Comparison of those two countries is full of contrasts. While Polish way to democratic transition was 'gentle revolution' or 're-folution' (term coined by T. G. Ash), Romania way to democratisation includes harsh revolution with public executions of the former dictator and his wife. Very peaceful and democratic looking process in Poland contrasts with wild revolution in Romania which is far from the democratic patterns. However, it was Romania after its revolution that legalised abortion; and it was Poland with its democratic process, that de-legalized it.

Poland and Romania represents two opposite directions of the socalled democratic transitions in former Eastern bloc. Other members and neighbours applied various patterns concerning reproductive right, but everywhere, they became the most significant component of transition ideology. Polish example might be followed by its neighbours: Polish politicians in Lithuania regularly call for ban on abortion; and also, neighbouring Slovakia experienced some initiatives to limit abortion in this country. Anti-abortion movement in East and Central European countries is very strong and have recently been supported by the anti-gender movements.

\section{Conclusion}

The policies towards or against reproductive rights do influence processes of transition in European countries. Limitation of reproductive right, extended in the strictest cases (as in Poland) to place a ban on abortion. However, this contradicts the popular approach to Eastern transformation such as democratization. More appropriate in this case should be the approach of Charles Tilly, who describes both the processes of democratization and de-democratisation. Consequently, I would suggest that the de-legalization of abortion in Stalin Russia, Ceausescu Romania, and democratizing Poland should be interpreted as signals of de-democratization turns. Polish researchers point out to the strong influence of the construct of Mother Pole model in influencing the definitions of gender roles. Thus, similar phenomena may be found in neighbouring countries, with less strict but occurring attacks on reproductive rights. The limitation of reproductive rights accompanied by the redefinition of feminity as maternity may also be a reflection of the nationalization of gender role models and domination of nationalist ideology in transforming countries. However, this may also become a threat to the democratization processes or even reversed it in the opposite direction. Anti-gender movements ${ }^{109}$ observed recently in many Eastern countries, seems to play similar role. Furthermore, cases of Portugal

\footnotetext{
${ }^{109}$ discussed at the conference in Kharkiv in 2013, published in «Гендер і антигендер» Гендерний журнал «Я» (№4 (34), 2013): http://ua.boell.org/uk/2013/12/30/gender-iantigender-genderniy-zhurnal-ya-no4-34-2013,
} 
and Spain shows that reproductive issues are still crucial for political discourses and decision making processes, and this phenomenon should be studied carefully.

\section{References:}

Aristotle, Politics, Chicago: University of Chicago Press, 2013.

Castells, Manuel, The Power of Identity, The Information Age: Economy, Society and Culture Vol. II. Cambridge, MA; Oxford, UK: Blackwell, 1997

Dunn, Elizabeth. Baby Food, Big Business, and the Remaking of Labor, Ithaca: Cornell Univeristy Press, 2004.

Einhorn, Barbara, Cinderella goes into Market. Citizenship, Gender and Women's Movements in East Central Europe, Verso: London, New York, 1993.

Giddens, Anthony, The Transformation of Intimacy: Sexuality, Love and Eroticism in Modern Societies. Cambridge: Polity. 1992.

Huntington, Samuel P. Democracy's Third Wave. The Journal of Democracy, 2(2), 1991.

Inglehart, Roland, Pippa Norris. The Rising Tide: Gender Equality and Cultural Change Around the World. New York and Cambridge: Cambridge University Press, 2003.

Kligman, Gail. The Politics of Duplicity: Controlling Reproduction in Ceausescu's Romania. Berkeley: University of California Press, c. 1998.

Mill, John Stuart, The Subjection of Women, (1869 first ed.). London: Longmans, Green, Reader \& Dyer. Retrieved 10 December 2012.

Plato, The Republic. New Haven: Yale University Press, 2006.

Tilly, Charles. Democracy, Cambridge University Press, 2007 